\title{
The Political Legitimacy of the Communist Party of China From the Perspective of Constitution
}

\author{
Liu Tianyuan ${ }^{1}$ \\ ${ }^{1}$ Graduate School, Party School of the Central Committee of CPC, Beijing, China \\ Correspondence: Liu Tianyuan, Master Candidate for Constitutional Law \& Administrative Law, Graduate \\ School, Party School of the Central Committee of CPC, No.100 Dayouzhuang, Haidian District, Beijing 100091, \\ China.
}

Received: December 22, 2017

doi:10.20849/ajsss.v3i1.353
Accepted: March 19, $2018 \quad$ Online Published: March 26, 2018

URL: https://doi.org/10.20849/ajsss.v3i1.353

\begin{abstract}
The Communist Party of China's political legitimacy is a result which is based on its unique advanced and excellent quality, combines the basic principles of Marxism-Leninism with the concrete practice of China, and gains the support of Chinese people because of leading Chinese people to overthrow the reactionary rule to establish a new completely people's political regime and putting forward the line and route which conform to the development direction and requirement of Chinese social history. That is to say, this is the objective result of the Chinese people's sincere choice and commitment, and then confirmed in the national Constitution, which condenses the fundamental will and interests of the Chinese people. The process of Chinese Constitution establishment and the Constitution's ideas and norms, both of them provide sufficient legal basis for the political legitimacy of the Communist Party of China. In that way, the continuation of the Communist Party of China's political legitimacy-leadership and governance-must adhere to the rule of Constitution.
\end{abstract}

Keywords: constitution, the Communist Party of China, political legitimacy, rule of constitution

\section{Introduction}

According to the theory of Social Contract, the public power comes from the transfer and granting of the people. Based on this, all public power and its operation must be based on the political legitimacy of the guidance of democratic theory in modern democratic society; otherwise it will lose the basis and reason for existence. Political legitimacy (Note 1) which is the ruling position and guarantees the ruling authority is the premise and foundation of governing the country and it contains two aspects of meaning. The one is the political ethics in the value level, such as fairness, justice and human rights. The other in experience is the consent of citizens, the election, the ruling performance etc.

A ruling party, or other type of ruler, has always pursued a goal, that is, to constantly enhance and expand its governance and legitimacy. As the ruling party of China, it is particularly important to pay attention to and strengthen the political legitimacy for the Communist Party of China (CPC). From the normative perspective, especially under the ruling concept of governing the country in accordance with the law, expounding the political legitimacy of the Communist Party of China has more legal basis from the fundamental law of the state - Constitution - that embodies the will of the people. The logical extension of the above is the basis for the long term ruling of the Communist Party of China, which must lie in Constitution to governing the country, that is, rule of Constitution.

\section{The Advanced Nature of the Communist Party of China is the Premise and Foundation of Political Legitimacy}

An advanced party, which is composed of advanced members, has the ability and qualification to lead the people to govern a country. The individual composition of the Communist Party of China's members and the ways and standards of developing and absorbing party members embody its overall characteristics and basic attributes, and reflect its basic nature and purpose. Compared with western political party to develop party members (Note 2), the Communist Party of China which has strict conditions and standards always have specific requirements (Note 3) strictly on its members. The party constitution of CPC emphasizes the absorption of party members from advanced elements (Note 4). 
Marx and Engels put forward that the working class political party, as a proletarian fighting organization, must have authority and concentration, so as to ensure the unity of will and action (Note 5). In order to maintain this authority and concentration, strict discipline must be carried out. Teng Hsiao-ping also stressed that the Communist must strictly observe the party's discipline, and abiding by the highest standards of discipline is to truly uphold and resolutely implement the party's and state policies (Note 6). Some scholars criticized the discipline of the Communist Party of China seriously violated the right of individual life of the party members. In essence, the party's discipline ensures that party members keep their progressiveness in their life style, work discipline and political ideology, thus providing the disciplinary to guarantee for the advancement of the Communist Party of China.

The progressiveness of the Communist Party of China is the basic pre-requisite for the recognition and support of the people, and this recognition and support of the masses are the source of strength and the inevitable result of the realization of the progressiveness of the Chinese Communist Party. The fundamental purpose of the Communist Party of China is to serve Chinese people wholeheartedly. On this foundation, the basic purpose of keeping advanced nature is to serve the people better. The long term ruling idea of the Communist Party of China and the important magic weapon for the Communist Party of China to maintain vigorous vitality and powerful fighting force is to persisting in serving the people wholeheartedly and the mass line and regarding the people as the source of the fundamental strength in the process of China's stepping into the world power and realizing the Chinese dream.

\section{Chinese Constitution Making is the Historical Choice of Chinese People's Democratic Constitutionalism}

Constitution is the value system of social community established with contract as its link. The subject of its constitution is only the whole people. Precisely, because the right to formulate constitution is the most direct embodiment of the people's sovereignty, the constitution has the highest normative effect (Note 7). As the subject of constitution formulation, the people's Congress of China's which is the fundamental political system of the provisions of Chinese constitution is a great creation-combining Marxism and Leninism people's state power theory with China's national conditions - made by the Communist Party of China. The universality of the people's representatives (Note 8) reflects the value pursuit of the various ethnic classes, democratic parties and people's groups under the leadership of the Communist Party of China and the fundamental interests of the people of the whole country, so it is more realistic and extensive. On the other hand, the legitimacy of the constitutional formulation's procedure also ensures the proper use and the legal status of the power of constitution formulation. For the legitimacy of the procedure, the ancient Greek philosophers believe that everything's process and the legitimacy of its procedures are one of the basic methods to ensure the development of things following the universal law. From the establishment of the people's Congress to draft, adoption and promulgation of the constitution, each procedure constitutes the orderly and unified whole of the constitutional procedural justice. The constitution making procedure of Chinese fully embodies the standardization and democracy.

As the leader of Chinese revolution, the Communist Party of China initially took revolution as an important means to realize democracy (Note 9), and regarded democracy as the core value of revolution. At the beginning enactment of the Chinese constitution, there are unique historical background and mission. The spirit of constitutionalism which is caused by the sense of historical mission makes the people's democracy have the inevitability of historical choice. The Chinese Communist Party led Chinese people to carry out the Chinese revolution and overthrew the reactionary rule of imperialism, feudalism and bureaucrat capitalism. The result is people's desire for democratic life actually reflected in the Chinese constitution. In a word, the Chinese constitution which conforms to the fundamental interests of the Chinese people and China's specific national conditions is the historical choice of people's democratic constitutionalism, and it has gained the most extensive mass foundation with democracy as its value orientation.

\section{Basic Values of the Constitution and Goals of the Communist Party of China are Identical}

The premise of realizing human rights is to establish a modern nation and political society. The view of social contract is that the people agree to alienate the rights and freedoms and the purpose of alienation is to make the state and society realize and protect these rights and freedom in the process of establishing. Marx and Engels took the all-round development of human beings as their basic starting point when they founded the theory of scientific socialism. In this basis, the fundamental purpose of the Communist Party of China is to serve the people wholeheartedly, and regard realizing the fundamental interests of the overwhelming majority of the people as the starting point and foothold of the ruling. As the foundation of all laws, Constitution's value lies in guiding, promoting and guaranteeing the all-round and free development of human beings, that is to say, the 
liberation of man. The purpose of the Communist Party of China's ruling is to lead and support the Chinese people to grasp the state power, protect the people enjoy extensive rights and freedoms in accordance with law, and respect and protect human rights, so as to realize the all-round development of human beings. There is no doubt that this value orientation is highly isomorphic with the value pursuit of the Communist Party of China.

Posteriorly, the constitution which represents the will of people can only be led and implemented by the party which can represents people, so as to get the basic guarantee that it does not violate the idea of the beginning of its formulation. The reason why the proletariat can be the unstoppable power is that it is consistent with the thought which is formed by the basic principles of Marxism and consolidated by the material unity of the organization (Note 10). To establish authority and promote the implement of Constitution must rely on the exemplary role of the organizations at all levels of the party which is closely related to the people. As a proletarian Party, the Communist Party of China has over 800 million members as their powerful resource, and it has complete organization structure, institution, norm and leadership system. All of these can effectively connect its members to take the lead in studying, respecting and obeying the Constitution in order to protect and promote the implementation of the Constitution through its different levels of organization.

\section{The Establishment of Leadership in the Constitution is the Legal Basis of the Political Legitimacy of the Communist Party of China}

Mao Zedong emphasized that a group should have a constitution, and a country also should have; the constitution is regulations; it is the fundamental law (Note 11). On the one hand, the constitution in the introduction, through reviewing and summarizing the great historical changes that have taken place since modern China, drawing the historical conclusion is that the success of China's revolution, construction and reform was achieved under the leadership of the Communist Party of China. It is also affirming the Chinese people of all nationalities will continue to move forward under the leadership of the Communist Party of China. Constitution, on the other hand, in the first article, clearly defines the nature of "the People's Republic of China is led by the working class and based on the alliance of workers and peasants of the people's democratic dictatorship of socialist countries" (Note 12) and the leadership of the working class must be implemented by its political party, the Communist Party of China as the Chinese working class, the Chinese people and the vanguard of the Chinese nation, to uphold the people's democratic dictatorship and the socialist constitution principle, must adhere to the leadership of the communist party of China. Therefore, the preamble of the constitution states the leadership of the CPC and the specific national system in the general class, which provides a strong basis for the political legitimacy of the Chinese communist party.

On the other hand, the Communist Party of China, as the ruling party of the country, has a very close relationship with the guiding ideology of the constitution. The guiding ideology of the constitution is the dominant ideology and reflection of the spirit of the age. It determines the content of the constitution and the validity and correctness of the constitution, embody a concentrated reflection of national will, interests and core values. The Communist Party of China in the process of summing up historical experiences and lessons, the combination of socialism and the Chinese concrete national condition, has made a scientific judgment of the primary stage of socialism, and established the party's basic line (Note 13) in the primary stage of socialism. Meanwhile, the constitution lives with four cardinal principles (Note14) as the general guiding ideology. So, the basic line of the Communist Party of China and the constitution of the guiding ideology are in line. It was satisfied with the guiding thought of the constitutional and at the same time making the most politically authoritative explanation so that the constitution of the guiding ideology more in line with the political and social reality.

\section{Ruling of Constitution is the Fundamental Legal Guarantee of the Political Legitimacy of the Communist Party of China}

The fundamental principles, basic tasks, basic rules and basic rights and obligations of citizens in the constitution are the basic theory, basic program, basic line and basic experience of the Communist Party of China, which are transformed into the embodiment of the will of the state through legal procedures. It is to solve the overall, fundamental, long-term problems in the country's political, economic, cultural, and social life. It is also the most fundamental of the Chinese Communist Party to govern and rejuvenate the country and lead the people of all nationalities to build socialism with Chinese characteristics. Therefore, the political legitimacy of the Communist Party of China is not self-appointed, but determined by the Constitution and then, after the political legitimacy of the Communist Party of China, it is necessary to institutionalize and legalize the way of organizing, grasping and controlling the state power that is, ruling the country according to the Constitution.

The Constitution stipulates that all political parties in the country must abide by the constitution, safeguard the dignity of the Constitution and guarantee the implementation of the Constitution (Note 15). Then, the political 
parties here naturally include the Chinese Communist Party, its behavior must be based on the provisions of the Constitution and the spirit. On the other hand, according to the principles and provisions of the Constitution, the Communist Party of China is the only political party with leadership and ruling legitimacy in China and has established the basic principle of constitutionalism that must adhere to the leadership of the Communist Party of China. Therefore, the power of the ruling party of the Communist Party of China is endowed by the Constitution and has a clear constitutional basis. The ruling of the constitution strengthens the constitutionality of its political legitimacy, and conforms to the basic principle of the supremacy of the people's sovereignty in the modern constitution. Judging from the world, the rule of law is the best form and path to make the ruling party in power. In the process of the transition from the traditional state to the modern democratic state, some countries have already established the constitutional system, but the cases of violation of the constitutional system also occur frequently. With the development of socialist democratic politics, the generation and operation of the power of the working class can be justified and legitimate only if it follows the rules prescribed by the Constitution. History and experience prove that the ability to take the initiative to jump out of the historical cycle of political parties, lies in whether the political party for the sake of political legitimacy for their own reasons, from the fundamental struggle for the people's heartfelt support. The serious challenge of the political legitimacy of the Communist Party of China is multifaceted (Note 16) and the most important challenge is whether the ruling and leadership can be brought into the orbit of the rule of law. The political basis and political purpose of the rule of law in China is totally different from the multi-party system and the separation of the three powers in the western capitalist countries. It is the essential difference between China and the western capitalist countries under the premise of adhering to the leadership of the Communist Party of China, and to adhere to the rule of law in the premise of Chinese under the leadership of the Communist Party, which is the essential difference between China and Western capitalist countries. The Constitution of the People's Republic of China is formulated under the leadership of the Communist Party of China and embodies the common will and fundamental interests of the whole people. At the same time, the Chinese Communist Party will lead the people to consciously abide by the constitution, be loyal to the constitution and resolutely oppose all acts that violate the constitution and damage the constitutional authority (Note 17). Only in this way it can be political legitimacy, and fundamentally get the support of the people. This is also the fundamental choice for the Communist Party of China to continue to improve the leadership of the party, win the trust and support of the people, enhance political legitimacy, and achieve long-term governance in the future.

\section{Conclusion}

Through the analysis above, we can draw such a conclusion. The purpose and goal of the Communist Party of China are in line with the spirit of the constitution in the normative and value level of political morality. Both of them are to protect human rights and the basic rights of citizens. Besides, at the level of experience and fact, the Communist Party of China has a high degree of people's identity and credibility because of putting forward the rule of law and rule of constitution according to the demand of modern rule of law. As the fundamental law of the state, the constitution strongly consolidates the political legitimacy of the Communist Party of China and ensures its implementation in the ruling party's established governing philosophy. On the other hand, the constitution also restricts and prevents the abuse of the leadership and the ruling power. In conclusion, constitution is the legal basis of political legitimacy of the Communist Party of China. Therefore, ruling of constitution must be the realistic necessity and fundamental choice for the long term ruling of the Communist Party of China.

\section{References}

Chen, Y. L., \& Jiang, Q. H. (2015). The Legal Analysis of the Leadership of the Communist Party of China. Legal System and Social Development, (3), 46-56.

Barendt, E. M., \& Barendt, E. (1998). An Introduction to Constitutional Law. London: 0xfoxd University Press.

Guo, D. H. (2015). Legal Interpretation of the Three Maxims of the Communist Party of China. Journal of Shandong University of Science and Technology (Social Sciences Edition), (3), 24-26.

Wheare, K. (1966). Modem Constitutions. London: 0xfoxd University Press.

Ma, Y. D. (2015). Deliberative Democracy, Construction of Rule of Law in China and Constitutional system development. Theoretical Study of the Chinese People's Political Consultative Conference, (1), 49-55.

Ma, Y. D. (2015). The Role of Consultative Democracy in a Constitutional System and the Rule of Law in China. Chinese Social Sciences (English Edition), 36(4), 5-23. https://doi.org/10.1080/02529203.2015.1088619 
Qin, Q. H. (2013). The Basis for the Long Term Ruling of the Communist Party of China--Ruling of Constitution under Constitutional Consensus. People's Forum, Academic Frontier, (8), 37-43.

Shi, W. L. (2013, August). Research on the Institutionalized Construction of Ruling by Law. Beijing: Chinese Social Science Press.

Song, H. C. (2011, May). The Ruling of Constitution and the Renewal of the Communist Party of China's Constitutional Concept. Changchun: Jilin People's Publishing House.

Wang, Z. M. (2013). Constitutional Politics: Open the Peace Road--How does the Communist Party of China Go Out of the Law of Historical Periodicity. People's Forum, Academic Frontier, (8), 16-30.

Xiong, H. (2006, April). Study on the Communist Party of China's ruling of law. Changsha: Hunan People's Publishing House.

\section{Notes}

Note 1. Political legitimacy refers to the special attributes of political power itself, thus obtaining the voluntary and continuous obedience of the ruling people or people.

Note 2. In fact, it is essentially different between the Communist Party of China adhering to the advanced and the western academia touted by the elite theory. Western elite theory is too personal heroism, but the advance of the Communist Party of China more represents a collective concept. To be correct, the advanced nature of the Communist Party of China is a unity and fusion of the Chinese tradition and the elite theory advocated by all western classes.

Note 3. The constitution of the Communist Party of China stipulates that "the member of Communist Party of China must serve the people wholeheartedly, sacrifice their own everything, and strive for the realization of communism for a lifetime. The Communist Party members of China are always an ordinary member of the working people. All members of the Communist Party should not seek any personal gain or privilege except for the interests and duties in the scope of the laws and policies."

Note 4. The constitution of the Communist Party of China stipulates that "Advanced people over the age of eighteen including Chinese workers, peasants, soldiers, intellectuals and other social classes who accept the party's program and constitution and is willing to participate in a party organization and in which work actively, carry out party resolutions and pay membership dues, may apply to join the Communist Party of china."

Note 5. Karl Heinrich Marx. Friedrich Engels. (1972). The complete works of Marx and Engels (volume twenty-ninth). Beijng: people's publishing house, pp.413.

Note 6. Teng Hsiao-ping, (1994). Selected works of Teng Hsiao-ping, (volume second). Beijing: people's publishing house, pp.367-368.

Note 7. L Hu Tng. (2002). The constitution essence, Taiwan: Yuanzhao publishing company, pp. 7.

Note 8. The Communist Party of China launched an unprecedented general election in 1953, held the first session of the first National People's Congress in 1954, and promulgated the Constitution of the People's Republic of China. More than 150 million Chinese people participated in the discussion of the first draft of the Constitution and put forward 1180420 amendments, additional comments and suggestions.

Note 9. The first program of the Communist Party of China determined that the fundamental political purpose of the party was to realize social revolution, and insisted on transforming the Chinese society thoroughly with revolutionary means in 1921.

Note 10. Vladimir Ilyich Ulyanov. (1995). Selected works of Lenin (volume first), Beijing: people's publishing house, pp.526.

Note 11. Mao Zedong, (1999). Selected works of Mao Zedong (volume 6), Beijing: people's publishing house, pp.328.

Note 12. Article 1 of the constitution stipulates that "the People's Republic of China is a socialist country under the leadership of the working class and the people's democratic dictatorship based on the union of workers and peasants".

Note 13. That is to insist on economic construction as the center, adhere to the four cardinal principles and the basic line of "one center, two basic points" of the reform and opening up.

Note 14. Constitution explicitly pointed out in the preface of "the Chinese people of all nationalities will 
continue to be under the leadership of the communist party of China, in under the guidance of Marxism-Leninism, Mao Zedong thought, adhere to the people's democratic dictatorship, adhere to the socialist road, adhere to the reform and opening up, constantly improve the socialist system......Socialist country."

Note 15. The Constitution stipulates that the people of all ethnic groups, all state organs, armed forces, political parties and social organizations, enterprises and institutions must take the constitution as the basic standard of conduct, and the duty to uphold the dignity of the Constitution and ensure its implementation responsibilities.

Note 16. For the Communist Party of China, continuing to enhance the political democracy, ideology, economic performance, social justice, and the relationship between the party and the masses are the factors that affect their political legitimacy.

Note 17. For the relationship between the Chinese Communist Party and the Constitution and the law, the party leads the people to formulate and abide by the Constitution and the law, and also the party must act within the scope of the Constitution and the law.

\section{Copyrights}

Copyright for this article is retained by the author(s), with first publication rights granted to the journal.

This is an open-access article distributed under the terms and conditions of the Creative Commons Attribution license (http://creativecommons.org/licenses/by/4.0/). 